\title{
EL ESPLENDOR DE LA FORMA. H.U. VON BAL- THASAR: UNA PROPUESTA METAFÍSICA
}

\section{THE SPLENDOR OF FORM. H.U. VON BALTHASAR: A ME- TAPHYSICAL PROPOSAL}

\author{
Manuel Palma RAMíREz ${ }^{1}$ \\ Centro de Estudios Teológicos de Sevilla
}

Recibido: 7 de diciembre 2018

Aceptado: 2 de mayo 2019

Resumen: ¿Es posible describir una metafísica en la obra de H.U. von Balthasar? El artículo que sigue propone una lectura ontológica del monumento cultura del pensador suizo desde tres claves importantes: el ser y los trascendentales, en la particular ordenación que Balthasar les dar; la cuestión de la diferencia y la forma en la perspectiva de la belleza.

Palabras clave: Balthasar, metafísica, forma, diferencia, belleza.

Abstract: Is it possible to describe a Metaphysics in the writings from $\mathrm{H}$. U. Balthasar? This paper proposes an ontological review of the big cultural monument from the Swiss philosopher, from three important keys: the human being and the transcendence, following the particular order given by Balthasar, the question of the difference and the form from the beauty perspective.

Keywords: Balthasar, metaphysics, form, difference, beauty.

1. Manuel Palma Ramírez (manuelpalma.es@gmail.com), sacerdote de la Archidiócesis de Sevilla. Estudió Filosofía en Sevilla, París y Roma. Doctor en Filosofía en la Pontificia Università Gregoriana (2011) y Licenciado en Teología (2006), por cuyo curriculum obtuvo el Premio extraordinario fin de carrera. Profesor de Metafísica en el Centro de Estudios Teológicos de Sevilla, del que es director (2018) 


\section{Introducción. Metafísica y crisis de la Ontología moderna}

La propuesta que se desarrollará a continuación, con pretendida fidelidad con los escritos de Hans Urs von Balthasar, trata de exponer las notas fundamentales del proyecto metafísico del pensador suizo. La primera cuestión que se impone es lógica: ¿hay acaso una metafísica en la obra de Balthasar? Es decir, ¿ha llegado este autor a proponer un itinerario ontológico propio? Y de ser así, ¿dónde se asienta ese recorrido a través del ser? ¿Cuáles serían los puntos de apoyo de esta metafísica? En el título propuesto se apunta el «esplendor de la forma» como criterio de lectura. Entonces, ¿es la forma el eje de su propuesta ontológica? Y todavía más, si tomamos la forma como centro, ¿de qué «forma» estamos hablando? ¿Alude Balthasar a la forma, acto supremo de Aristóteles? O, por el contrario, ¿su tesis es la de un esteta que se pierde en la superficialidad y no es capaz de adentrarse en la verdad del ser? Todas estas interrogaciones dejan ya entrever que la de Balthasar es una obra ante la que se han posicionado grandes defensores y, al mismo tiempo, grandes detractores. En cualquier caso, no cabe duda de que tal monumento teológico (y cultural) ha de ser calificado, por unos y por otros, como grandioso y original.

Aceptando este punto de partida, queda, no obstante, el deber de justificar la ocasión del tema, ¿cómo hablar de metafísica hoy? O mejor, ¿sigue teniendo sentido e interés una propuesta metafísica? Ante estas cuestiones, el propio Balthasar responde con gran realismo y, al mismo tiempo, proponiendo un análisis ciertamente incisivo. $\mathrm{Al}$ inicio del primer tomo de Gloria, describe cómo los distintos ámbitos del saber han ido dando de lado la belleza, desde las ciencias experimentales a la filosofía e incluso, en último término, la propia teología. La más pequeña de las hermanas del ser ha sido abandonada. Y ahora, siguiendo la imagen de Charles Péguy, ¿quién tirará, con esperanza viva, del amor y de la fe?

La mayoría de las cuestiones que se han bosquejado laten en el trabajo que sigue, apenas delineado de un modo filosófico (aunque no sólo). El punto de partida de este recorrido intentará plantear la propuesta ontológica del autor de Basilea: ¿qué entiende Balthasar por el ser? ¿Cómo articula en su obra la lógica de los trascendentales? ¿Qué lugar ocupa el encuentro entre el ente y el espíritu? ¿Cómo se revela el ente? En este primer aspecto se habrá de tener en cuenta la obra Verdad del Mundo, que marca decisivamente su lectura filosófica de la realidad. En un segundo momento, una vez asentados los principios generales de la metafísica, habría que preguntarse por la que Martin Heidegger consideraba patria de la ontología: el problema de la diferencia. ¿De qué modos está presente la diferencia en la obra de Balthasar? ¿Es la diferencia ontológica el punto de llegada de su metafísica? El tercer aspecto habrá de considerar, por úl-

Thémata. Revista de Filosofía №59 (2019) pp.: 13-34. 
timo, la belleza como elemento central de la recuperación de la metafísica hoy. Y de este modo, serán tratadas la identidad de la forma y las relaciones con ella, que han marcado, a juicio de Balthasar, las diversas épocas de la historia de la humanidad. Este tercer punto desemboca, atravesando la agonía eterna de Cristo, en la forma de la Gloria divina.

\section{El ser y los trascendentales. Propuesta ontológica}

Y entonces, ¿en qué consiste la propuesta metafísica de H.U. von Balthasar? Su pensamiento sobre el ser se sitúa en la tradición tomista de la distinción entre el existir y la esencia. No obstante, Balthasar usa igualmente el vocabulario de M. Heidegger el cual, a propósito de la verdad (a-létheia) habla de revelación del ser. Así, a juicio de Paul Gilbert, lleva la reflexión de origen tomista a una mayor pureza ontológica. De este modo, el inicio de su reflexión se sitúa en la aparición del ente ante la presencia del espíritu, un surgimiento del que el ente guarda en sí mismo la razón y que el pensamiento no agota nunca en sus determinaciones formales, según lo había reconocido el propio santo Tomás de Aquino en su obra De Veritate ${ }^{2}$. Este surgimiento del ente, su aparición, es tratada por el pensador suizo de un modo fenomenológico: «todo ente es desde el momento en que puede emerger en el designio secreto de Dios y entrar en la en la existencia concreta en la que está, como esencia que ha llegado a manifestarse, ante la mirada del conocimiento» ${ }^{3}$.

\subsection{La emergencia del ente y su intimidad. Conocimiento como libertad}

La revelación del ente al pensamiento, que coincide con su aparición en el mundo de las cosas cognoscibles, significa que el ente ha abandonado su origen cuando se ha dado al espíritu que lo acoge benevolentemente, con una actitud "de compasión», sin defensa ${ }^{4}$. Así, el descubrimiento que representa el esfuerzo del sujeto es, él mismo, una parte esencial del desvelamiento del objeto ${ }^{5}$.

Esta revelación del ente acontece de un modo misterioso, puesto que no significa una completa mostración del ente al espíritu que lo recibe: las cosas no son sólo el objeto de una mostración, sino que permanecen, también hasta el final, como esencialmente secretas. El ente no es por

2. P. Gilbert, Metafísica. La paciencia de ser, Salamanca 2008, 255

3. H. U. von Balthasar, Teológica, I. Verdad del mundo, Madrid 1997, 233.

4. Ibid., 234.

5. Ibid., 65 .

Thémata. Revista de Filosofía Nº59 (2019) pp.: 13-34. 
tanto pura transparencia, sino «opacidad relativa» ${ }^{6}$. Las cosas se revelan como secretas y solo así, bajo esa forma, se convierten en objeto de conocimiento. El velamiento del ser no es mera ausencia o negación, sino la manifestación de su dignidad de objeto y de su propia libertad. El fundamento de su valor único e intransferible radica precisamente en ser autónomo: el valor del ser-para-sí que le ha sido dado exclusivamente a ellas.

Si las cosas no poseyeran el más mínimo valor propio, tampoco podrían pretender una esfera reservada sólo para ellas, no podrían ofrecer secreto alguno y ni siquiera serían apetecibles para el pensamiento. De hecho, el ente sería entonces, según su esencia, un objeto para el sujeto, que carecería enteramente de libertad en su misma mostración, estaría por completo desamparado en su revelación: sería una cosa totalmente carente de derechos, de la que el sujeto que conoce podría disponer según su capricho. Al perder su carácter único e irrepetible, su intimidad, la existencia extraviaría todo su sentido, dejaría, por tanto, de existir el misterio esencial que circunda el ente. Y, afirma Balthasar, el ser, sin misterio, estaría «como prostituido» ${ }^{7}$.

Sin embargo, todos los seres poseen, desde el acto mismo de su creación, una espontaneidad para hacerse exteriores, que reproduce un eco lejanísimo de la infinita libertad mayestática del Creador. La intimidad del ente puede admitir muy diversas formas y grados, que garantizan el carácter único e irrepetible, en cierto modo solemne, de cada revelación. No hay ente alguno que no posea al menos una rudimentaria intimidad: esto que se admite en general para los seres vivientes, no deja de ser válido, según Balthasar, para los grados ínfimos del ser: tampoco los seres sin vida son una presa meramente pasiva para el conocimiento, antes bien, en ellos, existen fuerzas en acción que se exteriorizan, que llevan a cabo un movimiento que los desplaza de dentro hacia afuera. Esta dinámica permite ver cómo la realidad no es sólo facticidad y casualidad, sino principalmente una riqueza que desborda a todo saber que la conozca. A ello se refiere Balthasar como «la coquetería del embozo» que domina la realidad de los entes y deja, a quien cree haberla aprehendido, con la sola vestidura de su aparición, al sustraerse de su aprehensión ${ }^{8}$.

6. Cf. P. Gilbert, Metafísica. La paciencia de ser, 256.

7. H. U. von Balthasar, Teológica, I. Verdad del mundo, 84.

8. Ibid., 86-87.

Thémata. Revista de Filosofía Nº59 (2019) pp.: 13-34. 


\subsection{El encuentro con el espíritu. Revelación y don}

Las cosas poseen su propio valor existencial que no se agota en ser objeto de conocimiento y, aunque no se cierran a este conocimiento, el sujeto cognoscente debe atrapar al vuelo lo que de ellas pueda tomar, sabiendo, no obstante, que la realidad será siempre infinitamente más rica y más grande que lo que él pueda coger de ella9.

De este modo, al vuelo, el ser se entrega a la acogida del espíritu. Así, bien podría decirse que todo conocimiento es espiritual, humano, ya que el ser humano está constituido de forma que ningún ente pueda serle extraño -resuena aquí el mandato del Creador: «poned nombre a las criaturas»-. El sujeto puede aprehender cada ente, pero sólo a condición de que el ente íntimamente se le ofrezca: el poder del conocimiento para recibir la revelación de las cosas es ilimitado, pero no así el poder para forzar la revelación. El ente se manifiesta bondadosamente y hace posible el acto de conocer.

El conocimiento deja entonces de ser considerado algo universalmente accesible y se transforma en una realidad libre y personal que determina, tanto de parte del que comunica, como de la parte del que recibe, una actitud totalmente nueva. En el que comunica, la comunicación comienza con una decisión libre de compartir con otro lo que le es peculiar, mientras que la libertad del espíritu consiste en la apertura de lo ajeno que, paradójicamente, lo abre a su propio ser, al autoconocimiento. «Sólo acogiendo lo ajeno y manteniéndose abierto a lo ajeno, sólo entregado a lo extraño y sirviendo a lo extraño puede el espíritu humano reclamar su ser propio» ${ }^{10}$.

\subsection{El ritmo de la aparición: encuentro y trascendentales del ser}

Este encuentro, entre el ente que se entrega y el espíritu que se dispone a su presencia, despierta confianza en el bien y abre hacia una búsqueda siempre infinita: funda la autoconciencia del espíritu y lo orienta a la medida del ser en su totalidad. La verdad sobre un ente singular proporciona, al mismo tiempo, la abertura del horizonte del ser en gene$\mathrm{ral}^{11}$. La doctrina de los trascendentales traba la comprensión de este acto. Los transcendentales son articulados, de hecho, a partir de la experiencia del ente en el que el ser se manifiesta y se vela. La doctrina de los trans-

9. Ibid., 90 .

10. Ibid., 98 .

11. Ibid., 223.

Thémata. Revista de Filosofía №59 (2019) pp.: 13-34. 
cendentales expresa el don que el ser hace de sí a partir de sí, preparando en el espíritu espacios infinitos para la aventura de la investigación intelectual $^{12}$.

En el encuentro, de nuevo, el ser comparece a través de sus trascendentales, forjando una verdadera alianza con el pensamiento. Es clásica la imagen del niño en brazos de su madre que usa Balthasar para hacer ver la pureza de ese encuentro por la que el ser se entrega al espíritu:

el niño está llamado a la conciencia de sí por amor de la madre. El horizonte del Ser infinito se abre a él revelándole cuatro cosas: que él es uno en el amor con su madre a pesar de no ser su madre; que este amor es bueno y, entonces, todo el Ser es bueno; que este amor es verdadero y, entonces, todo el ser es verdadero, que este amor suscita alegría y, entonces, todo el Ser es bello. El Uno, el Bien, lo Verdadero, lo Bello: es lo que llamamos atributos trascendentales del Ser porque superan todos los límites de las Esencias y son co-extensivos al Ser ${ }^{13}$.

Esta metáfora ofrece un acceso nuevo a los trascendentales: «es en el movimiento del ser donde se fundan la verdad, la bondad y la belleza» ${ }^{14}$. Los trascendentales son diversos aspectos de ese movimiento y de esa polaridad del ser. A partir de la polaridad del ser, con su diferencia expresiva y constitutiva (unum), surgirán las demás manifestaciones del ser: el mostrar-se (pulchrum), dar-se (bonum) y decir-se (verum) del ser. Esta tríada de trascendentales está fundada en el carácter epifánico del ser real ${ }^{15}$. No en vano, los trascendentales, desde su comprensión filosófica en la Edad Media, son considerados determinaciones universales que pertenecen al ser como tal y que, por tanto, trascienden toda especie y categoría, superan todo limite de esencia y son co-extensivos con el ser, de forma que se predican de todo ente y, como él, son indefinibles ${ }^{16}$.

En su obra Epílogo, con la que se cierra su Trilogía (Gloria, Teodramática, Teológica), el pensador suizo remite la estructura de su pensamiento teológico a la articulación de los transcendentales, esto es, «las propiedades del ser, que traspasan todo ente particular» y que «parecieron ofrecer el más apropiado acceso a los misterios de la teología cristiana» ${ }^{17}$. Afirma Balthasar: «nuestra estética, dramática y lógica se han construido sobre esta iluminación recíproca». Es decir, de las propiedades trascenden-

12. P. Gilbert, Metafísica. La paciencia de ser, 256.

13. H. U. von Balthasar, «Intento de resumir mi pensamiento»: Communio (ed. española) 10, IV (1988) 284-288.

14. H. U. von Balthasar, Gloria, I. Una estética teológica, Madrid 1985, 543.

15. Cf. J. Villagrasa, «La metafísica de H.U. von Balthasar»: Alpha Omega, X, n. 3, 2007, 334-337.

16. Ibid., 335 .

17. H. U. von Balthasar, Epílogo, Madrid 1998, 46.

Thémata. Revista de Filosofía №59 (2019) pp.: 13-34. 
tales del ser se han resaltado tres: bello, bueno, verdadero. Las cuales, por este orden «desacostumbrado», han conformado la Trilogía ${ }^{18}$.

\section{Metafísica y diferencias}

La doctrina de los trascendentales en la obra de Balthasar requiere, no obstante, la seria consideración de la diferencia. La problemática de la diferencia ha caracterizado desde siempre el discurso de la filosofía. Descrita de un modo general, esta problemática considera que los entes, múltiples y distintos entre sí, reenvían espontáneamente unos a otros y se unifican en un principio que no forma parte de la serie de los entes y que, por naturaleza, es universal, superior, y diferente a aquello que unifica.

En su artículo de 2007, La metafísica de H.U. von Balthasar, el profesor Jesús Villagrasa pone de relieve hasta qué punto es fundamental el aspecto de la diferencia en la obra del pensador de Basilea, desde la imagen misma del niño en brazos de su madre, al tiempo que separa cuatro tipos de diferencias, sin las cuales no podría entenderse el sentido teológico de los trascendentales. Esta doctrina requiere poner de relieve: la diferencia óntica entre las diversas realidades del mundo, la diferencia ontológica entre el ser y el ente, la distinción real entre la esencia y el ser y, más profundamente, la diferencia entre ser en general y Dios ${ }^{19}$.

\subsection{Diferencia óntica}

La primera diferencia es la que existe entre los entes del mundo, y, de un modo particular, la diferencia interpersonal yo-tú. Ahora bien, «si se toma ser en el sentido de realidad, entonces algo que es realmente no posee una parte del ser real en sí, sino todo el ser entero, aunque junto a él haya otras innumerables cosas reales. Los entes son distintos unos de otros y están separados unos respecto de otros, pero su ser real no es subdivisible» ${ }^{20}$.

Todo ello aparece claramente en la imagen: el hijo no es la madre.

\subsection{Diferencia ontológica}

Esta consideración inicial, que no parece ofrecer mayor dificultad especulativa, abre a la segunda diferencia: la diferencia ontológica entre el ser y los entes. «El todo de la realidad existe en el fragmento de un ente

18. Ibid.

19. E. PÉrez Haro, El misterio del ser. Una meditación entre Filosofía y Teología en Hans Urs von Balthasar, Barcelona 1994, 295

20. H. U. von Balthasar, Epílogo, 47.

Thémata. Revista de Filosofía No59 (2019) pp.: 13-34. 
finito, pero el fragmento no existe más que por el todo del ser real» ${ }^{21}$. El ser es acto y como tal se comunica al ente y se da sin cesar, sobre todo al vincular entre sí a los propios entes. El fondo del ser es la comunicación; este fondo es inmediatamente uno con el bien, es decir, con el amor que se da $\sin$ reserva y $\sin$ motivo $^{22}$.

No puede negarse que estas reflexiones de Balthasar están influenciadas por Heidegger, ahora bien, según Balthasar el filósofo de la Selva Negra no había delimitado bien la diferencia ontológica entre el ser y los entes, llevando el problema a una indescifrable esfinge ante la cual el hombre no puede vivir ni amar. En otras palabras, Heidegger oculta la Gloria de la Verdad. Para él, al ser sólo se accede por su limitación, ya que el ser se retira y se desvanece en la indeterminación, más en consecuencia, una reflexión sobre la belleza para reconocer en ella la gratuidad esencial, la pura irradiación de lo verdadero y del bien, del ser que apareciendo colma de alegría el espíritu y revela su belleza activa ${ }^{23}$.

\subsection{Diferencia esse-essentia}

La tercera diferencia es un correlato de la anterior. Es verdad que santo Tomás de Aquino no había hablado de diferencia ontológica, aunque no desconocía el problema filosófico de fondo, que, colocado en el interior del ente, el Aquinate no rehuyó. En santo Tomás aparece la distinción real esse-essentia que el hombre puede escrutar porque, por su espiritualidad, está abierto al todo, y de este modo también a la «experiencia de realidad», él, «que se sabe fragmentario, en medio de los innumerables fragmentos de ente del mundo» ${ }^{24}$.

La plenitud del ser, remarca el pensador suizo, sólo llega a ser real en el ente singular; pero el hecho de que el ser (heideggeriano) pueda explicarse sólo en la existencia (espíritu) comprende la dependencia del ser con respecto a lo existente y, de este modo, su no-subsistencia ${ }^{25}$.

\subsection{Diferencia ser-Dios}

Esa tercera diferencia, sin embargo, no logra dar razón ni del ser ni de las esencias, ni de la universalidad del ser ni de su no-subsistencia. Esta diferencia reclama una fundación en la cuarta, de carácter teológico:

21. Ibid.

22. Cf. H. U. von Balthasar, Teológica, I. Verdad del mundo, 251-253.

23. Cf. P. Gilbert, Metafísica. La paciencia de ser, 261-262.

24. H. U. von Balthasar, Epílogo, 48.

25. H. U. von Balthasar, Gloria, V. Metafísica. Edad Moderna, Madrid 1996, 568.

Thémata. Revista de Filosofía №59 (2019) pp.: 13-34. 
la diferencia ser-Dios, o más radical, Dios-mundo ${ }^{26}$. La pregunta primordial de la metafísica "ipor qué hay algo en vez de nada?», encuentra su respuesta última en la libertad y en el amor de Dios. «La libre profundidad personal del ser absoluto que se da, saca finalmente a la luz el secreto de la creación, la cuarta diferencia. Dios es el absolutamente Otro sólo en cuanto non-aliud, no-otro, en la expresión de Nicolás de Cusa» ${ }^{27}$. Si Dios «libremente crea el mundo y así comunica al mundo, al conferirle su no-necesidad gratuitamente, algo del estilo de su libertad, de su capacidad donante, libre y sosegada, y si esta libertad dadora no merece otro nombre que el de amor: ¿de qué otra "materia" podría entonces "ser" Dios, sino de "amor"?»" 28

En fin, las cuatro diferencias permiten adentrarse en el misterio del ser. El esse, participación primera y ejemplar de Dios, que entra directamente en la constitución de las cosas, y que no es Dios. La elevación de Dios por encima del ser garantiza definitivamente la trascendencia de Dios frente al mundo, cerrando las puertas a todo ontologismo y panteísmo: de igual modo, la inmanencia de Dios en el ser, y a través de este en el mundo, se las cierra también a todo deísmo y secularismo. La doctrina del ser es, para Balthasar, una mediación que permite el contacto entre Teología y Filosofía. Concluye en su artículo el padre Villagrasa que el misterio del ser es la fuente de todo el pensar filosófico y religioso de la humanidad en su búsqueda a tientas de lo divino y que dicha búsqueda es ya una respuesta humana a la primera palabra y revelación divina en el ser ${ }^{29}$.

\section{El esplendor de la forma}

En una perspectiva estrictamente metafísica, Balthasar hace pasar del ente expresivo a su origen ontológico, el ser. De este modo, conduce a la belleza, es decir, al ser que, apareciendo, colma de alegría el espíritu y muestra su belleza activa. No en vano, Balthasar sitúa al principio de su Trilogía los siete volúmenes de Gloria, una estética teológica. Su desarrollo arranca con la consideración del pulchrum. Así, en el pórtico de esta obra, se hallan estas sugerentes expresiones: «nuestra palabra inicial se llama belleza. La belleza es la última palabra que el intelecto pensante puede atreverse a pronunciar, porque ella no hace otra cosa que coronar, cual aureola de esplendor inalcanzable, el doble astro de lo verdadero y del

26. J. Villagrasa, «La metafísica de H.U. von Balthasar», 327.

27. H. U. von Balthasar, Gloria, V. Metafísica. Edad Moderna, 574.

28. Ibid., 586.

29. J. Villagrasa, «La metafísica de H.U. von Balthasar», 333.

Thémata. Revista de Filosofía №59 (2019) pp.: 13-34. 
bien y su indisoluble relación $»^{30}$. A continuación, el gran pensador de Basilea afirma: «esa es la belleza desinteresada sin la cual el viejo mundo era incapaz de entenderse, pero que se ha apartado de puntillas del moderno mundo de los intereses, para abandonarlo a su oscuridad, a su tristeza. Esa es la belleza que ya no es amada y custodiada ni siquiera por la religión». Y concluye: «quien, en su nombre, crispa los labios en una sonrisa, juzgándola como el juguete exótico de un burgués, de éste se puede estar seguro que -secreta o abiertamente- no es capaz de rezar y, pronto, ni siquiera de amar» $^{31}$.

\subsection{Belleza y forma: la forma de la aparición}

El olvido de la belleza coincide con la crisis de la Metafísica: al perder de vista uno de los trascendentales del ser, los demás se acaban olvidando (la verdad pierde contundencia, el hombre queda perplejo ante el bien) y, el propio esplendor del ser se desvanece ${ }^{32}$. Aparece entonces en la obra de Balthasar un signo de la doctrina clásica de la conversión con la que Felipe Canciller enfrentó la herejía maniquea de los cátaros mostrando que el ente era bueno y verdadero y que ninguna de estas propiedades puede cercenarse sin dejar de anular también a las demás. «Son inseparables, se inter-penetran, precisamente porque reinan conjuntamente por todo el ser» ${ }^{33}$.

Pero, ¿cómo puede ser comprendida la belleza? ¿Cómo es posible, en definitiva, presentar el sentido de este «primer» trascendental del ser? La respuesta la ofrece el propio Balthasar cuando afirma: «todo ente mundano es epifánico, precisamente en la diferencia descrita. El principio se muestra esencialmente en la forma de la aparición... El ente tiene una forma que se muestra como unitaria... La forma de aparición del ente es el modo como éste se expresa,... no sólo a sí mismo, sino a la realidad total presente en él, que remite a lo real subsistente: "los cielos proclaman la gloria de Dios" ${ }^{34}$. La forma, por tanto, es, en último término, la irradiación de la gloria del Señor ${ }^{35}$. Todo ente pone una forma que el ojo es capaz de ver

30. H.U. von Balthasar, Gloria, I. La percepción de la forma, 22.

31. Ibid., 22-23.

32. Cf. Ibid., 23.

33. H. U. von Balthasar, Epílogo, 46.

34. Ibid., 55.

35. H.U. von Balthasar, Gloria, I. La percepción de la forma, 26.

Thémata. Revista de Filosofía No59 (2019) pp.: 13-34. 
y que suscita la interpretación, aunque, de nuevo, la epifanía precede toda posibilidad de interpretación.

Esta forma es, en el caso del hombre, la expresión de su alma, de manera que no es extraña a él, sino tan íntima que vale la pena identificarse con ella, una forma otorgada desde el fondo del ser, no caprichosa, irrepetible, personal. Se trata, por tanto, de una forma vital, dispuesta y pronta para ennoblecer su propia vida cotidiana. ¿Qué es el hombre sin la forma, que en definitiva, es su propia ley individual? Para vivir en esa forma originaria es preciso haberla vislumbrado, poseer la capacidad espiritual para percibir las formas de la existencia en una actitud de profundo respeto ${ }^{36}$.

\subsection{El pensamiento de la forma}

Hasta tal punto la forma determina la vida de los hombres que es posible establecer una historia de la humanidad desde su relación con la forma. El autor suizo distingue cuatro grandes momentos de la historia determinados por modos concretos de relación con la forma: en primer lugar, las épocas que, enamoradas de las formas originarias de la existencia, intentan imitarlas y expresarlas por doquier; en segundo lugar, las épocas dominadas por la representación (y el deslizamiento hacia formas secundarias); en tercer lugar, las épocas en las que el hombre, por negar las formas, desespera de la dignidad de su existencia y reniega del mundo que destruye su propio ser-imagen; y por último, en cuarto lugar, las épocas en las que se produce la manifestación de la belleza a través de la abundancia de las formas engendradas ${ }^{37}$.

\subsubsection{Imitación de las formas originarias}

De acuerdo con el recorrido de Balthasar, el primer modo de relación de los hombres con la forma es la imitación.

La noción de imitación está presente desde sus orígenes en la historia de la filosofía ${ }^{38}$. No es extraño entonces vincular la imitación con la doctrina de la mímesis platónica. Para Platón, la mímesis representa el eje de toda una propuesta gnoseológica: el hombre conoce porque las formas mundanas evocan en su espíritu las formas del mundo divino. Esta categoría expresa, por un lado, el abismo entre el mundo de las ideas (la región ontológica por excelencia) y el mundo físico: entre la idea y su imitación

36. Ibid., 27.

37. Ibid., 28.

38. Ibid.

Thémata. Revista de Filosofía Nº5 (2019) pp.: 13-34. 
media una distancia que no puede ser salvada, la cual representa además dos grados diversos de ser, dos regiones ontológicas distintas. Así, de un modo evidente, para Platón, el artista es el que imita las formas divinas. Aristóteles había considerado, del mismo modo, la mímesis como fundamento de las artes: «dos causas, y ambas naturales, han concurrido generalmente a formar la poesía. Porque lo primero, el imitar, es connatural al hombre desde niño... Lo segundo, todos se complacen de las imitaciones, de lo cual es indicio lo que es plasmado en los retratos» ${ }^{39}$. Pero también en la República, Platón despliega una organización ideal del estado, es decir, la organización de la política está atravesada igualmente por el deseo de imitar el mundo de las ideas. No en vano, el estado platónico evoca el modelo en el que lo múltiple converge en una unidad justa: se puede observar cómo la idea de justicia genera simetrías entre los distintos niveles de la psyque y de los grupos sociales, y también entre los diversos planos de la ciencia y del intelecto ${ }^{40}$. La organización política llega a expresar, de esta manera, los valores más elevados: fortaleza, templanza, prudencia, justicia.

La idea de mímesis, con la que, en el Fedro, Platón había designado la relación que existe entre las cosas terrenas y los arquetipos celestes de los cuales son su imitación; alcanza su sentido más elevado en la versión de los LXX en donde el término se toma para referir la forma. En el Nuevo Testamento, además de tener el sentido de imitación (Rom 5,14), significa claramente forma: sobre todo en Flp 2,7, donde Cristo asume la forma de siervo y se hace semejante a los hombres, de acuerdo con el matiz introducido por el autor de Hebreos: se vuelve semejante a nosotros en lo que respecta a la forma humana $(\mathrm{Hb} 4,15)^{41}$. Por ello, la semejanza (homoiôma) que pone en juego la imitación dice mucho más que una mera aproximación abstracta, encierra un elemento formal. De hecho, la teología sobre el bautismo muestra cómo, en el bautizado, la forma-imagen es impresa a partir de la forma originaria que es Cristo. No se trata de conectar sólo externamente el arquetipo y la imagen, sino de afirmar en la ceremonia de la inmersión la muerte y la renovación que experimenta el bautizado bajo la impronta de la muerte de Cristo, objetivamente presente. De acuerdo con la forma de Cristo quedará, por tanto, configurada toda la existencia del bautizado ${ }^{42}$.

Este sentido profundo de la imitación, aunque referida a una realidad irrenunciable para el ser humano, corre el riesgo de desembocar,

39. ARistóteles, Poética, 1454b 5-15

40. P. Gilbert, Metafísica. La paciencia de ser, 283-284.

41. H.U. von Balthasar, Gloria, I. La percepción de la forma, 513.

42. Ibid., 514 .

Thémata. Revista de Filosofía №59 (2019) pp.: 13-34. 
según Balthasar, en el empequeñecimiento y en el vacío, que arrojan al hombre en brazos de la indiferencia ${ }^{43}$. Una vacuidad que puede alcanzar incluso la vida de la entera forma eclesial, haciendo que deje de ser creíble como institución de Cristo. Así lo constata el propio Balthasar al recurrir al relato del Gran Inquisidor, de F. Dostoievski. En él, Iván Karamazov, el autor de esta sátira espeluznante, presenta el intento de hacer plausible la forma corriente de la Iglesia ante Cristo prisionero, mostrándola como una falsificación necesaria y, por ello altruista, de la idea que Cristo tenía de ella. La institución descarga a la inmensa grey de la responsabilidad que ésta es incapaz de asumir, ya que la exigencia del Señor sólo puede ser vivida por los elegidos: la masa no puede pensar por sí misma y, puesto que no puede decidir con plena libertad, la jerarquía decide por ella. Así aparece el empequeñecimiento de una forma que la Iglesia adopta por concesión a las circunstancias, al tiempo que se demuestran dos cosas: lo humanamente plausible que es una religión semejante y cómo ésta se erige en una bofetada en el rostro del auténtico cristianismo ${ }^{44}$.

\subsubsection{Representación y formas secundarias}

A este modo inicial de imitación, le han seguido épocas marcadas por la representación de la forma. La noción de representación es fundamental en la historia del pensamiento gnoseológico. De hecho, la relación entre conocimiento y realidad es articulada, desde un punto de vista filosófico, bajo las exigencias de validez y de legitimidad. Especialmente durante la Modernidad, lo real es pensado desde la idea, esto es, desde la representación mental de la cosa extra-mental. A pesar de las diferencias en la explicación de la formación de las imágenes o de los conceptos en la mente, las diversas teorías filosóficas de la representación tenían una preocupación en común: la de establecer la correspondencia entre las imágenes y las cosas reales. Ya que las imágenes tienen una semejanza con las cosas, la validez del conocimiento y su valor veritativo se determinan en la correspondencia o adecuación entre el contenido mental en forma de imágenes o conceptos y la cosa extramental.

La principal tentación de esta manera de relación con la forma es la pérdida de contacto con las formas originarias y el deslizamiento continuo hacia las formas secundarias. Antonio Rosmini describe este error como la confusión de la idea con la realidad, que conduce a absorber todas las cosas en la ciencia y en el pensamiento que la produce. Cuando las cosas conservan su relación con las ideas, son iluminadas por éstas, se hacen

43. Ibid., 28.

44. Ibid., 506-507.

Thémata. Revista de Filosofía Nº59 (2019) pp.: 13-34. 
cognoscibles. Si la cosa se distancia de la idea mediante la abstracción constante, súbitamente se convierte en un enigma. La filosofía alemana ha considerado lo real dividido totalmente de la idea, de manera que lo real ha devenido imposible. Lo real dividido de la idea es desconocido, pero la forma secundaria que es la idea no tiene en sí lo real, no lo hace surgir, ni lo puede absorber en sí. Lo real existe con la idea, no en la idea, como si fuera un momento de ésta. La idea no puede estar sin lo real ${ }^{45}$.

La antropología que se deriva de esta relación con las formas secundarias es reductiva y, en un cierto sentido ideológica. El hombre, afirma Rosmini, ha sido reducido al solo pensamiento y las ideas, a simples producciones y modos suyos, confundiéndose así necesariamente con las $\operatorname{cosas}^{46}$. Todo se somete bajo este hombre sin límites que se parece al Fausto de Goethe, del que Herder dijo: «queda por saber si el hombre tiene derecho a elevarse a esta región, donde todos los sufrimientos, verdaderos o falsos, le dan lo mismo; donde aunque no deje de ser artista, deja de ser hombre, donde la luz, aunque resplandezca, ya no fecunda nada; y si esta máxima, una vez admitida, no implica la negación absoluta del carácter humano» ${ }^{47}$.

\subsubsection{Negación}

Esta manera representativa de relación con las formas trae consigo un nuevo contacto ellas: la negación. Negar las formas implica profanar y humillar al ser humano, ponerlo frente al sinsentido de la existencia y la desesperación. El mundo que niega las formas rechaza y destruye, en último término, el ser-imagen del hombre, esto es, lo confina en el vacío.

Pero, ¿cómo será posible salir de esta situación que el propio Balthasar juzga una tarea inhumana? Quizá, afirma el pensador de Basilea, sólo sea posible llevar a cabo una obra tal de una manera cristiana. El pobre humillado del Evangelio, despreciado por todos, oculto para el mundo que, sin embargo, es capaz de irradiar creadoramente sobre el mundo desde su centro. Ese que, soportando el peso de todo, aprende a ver la forma originaria del hombre en la existencia y, con audacia, la que procede de la confianza en el destino de esta forma, pone de relieve la verdad, la bondad y la belleza ${ }^{48}$.

Balthasar concibe esta época de negación como espejo del momento actual: válida para explicar el tiempo presente. Quizá sea Blaise Pascal, al

45. A. Rosmini, Introducción a la filosofía, Madrid 2011, 138-144.

46. Ibid., 136.

47. Ibid., 141.

48. H.U. von Balthasar, Gloria, I. La percepción de la forma, 28-29

Thémata. Revista de Filosofía №59 (2019) pp.: 13-34. 
que el pensador suizo consagra uno de sus estilos laicales ${ }^{49}$, el que mejor representa esa intuición de la Gracia que permite al hombre ser rescatado de la huida permanente de un mundo que lo arrastra sin conciencia hacia la muerte. La aspiración a la felicidad, de la que todos los hombres participan, no es sino una cicatriz y una huella vacía del amor que perdieron, es decir, el signo de la forma que fue negada en el mundo y que vanamente trataría de llenar el hombre con las cosas que le rodean. Sólo Dios puede colmar ese vacío. Entonces paradójicamente el mundo vacío de forma muestra en todo al Dios perdido.

El fragmento de los Pensamientos conocido como la «apuesta» (infini-rien) sitúa al hombre entre lo infinito, que es su verdadera patria, y la nada, que se abre de par en par, puesto que el hombre ha perdido su verdadero infinito, por el pecado original que lo trasladó del orden de la verdad al de las imágenes. Este desgarro interior de lo humano es vinculado a una unidad cuyo significado es la revelación del amor de Dios al hombre: en Jesucristo se reconcilian todos los contrarios. Como hombre y como Dios, Jesucristo es todas las cosas, las sublimes y las abyectas, para santificarlas en sí mismo. Cristo es la instancia omnicomprensiva, es el mysterium. Por eso, la agonía de Cristo dura hasta el fin del mundo, con un dolor eterno del que se apropia de forma representativa. La huella vacía del amor perdido en el pecador no le permite calcular la distancia que le separa de su autenticidad, de su realidad originaria antes de la negación de la forma.

La figura brota sólo en el instante en que el paréntesis de la unión hipostática, de Dios y hombre, abraza las dos situaciones, superándolas con su comprensión y con su trasvase valorativo. La operación del amor que viene de Dios no sólo confiere sentido, sino que crea forma. El hombre debe conquistarse su eterna felicidad, que es Dios, no por la demostración racional y metódica de su existencia, sino en virtud del ímpetu de su corazón, por la audacia de una apuesta personal, llegando de este modo a contemplar la certeza de la verdad.

\subsection{Engendramiento y fidelidad. El esplendor de la forma}

El esplendor de la forma aparece, de un modo escatológico, en el último de los modos de relación que señala Balthasar. Es la época en la que la belleza parece manifestarse por doquier a través de la desbordante abundancia de las formas engendradas: envuelve y baña toda la existencia

49. Cf. H.U. von Balthasar, Gloria, III. Estilos laicales, Madrid 1986, 179-241.

Thémata. Revista de Filosofía №59 (2019) pp.: 13-34. 
y exige el bien, porque obliga al hombre a permanecer fiel a la sublimidad del contenido vital cuyas formas representa.

La teología cubre su último estadio en el acto de adoración admirativa de la belleza que persiste inescrutable en sus formas. El silencio central que Dionisio Areopagita ${ }^{50}$ considera la Palabra primordial unificadora que está por encima de todas las palabras que tienen sonido. Cuanto más alto vibra su eco, más palabras son necesarias para traducirla. Pero la teología habrá de evitar la pretensión de explicar las cosas hasta el infinito, para, de este modo, respetar en silencio lo escondido de Dios que sobrepasa a los hombres.

La liturgia sagrada es el marco donde Dionisio encuentra la narración del misterio de la Resurrección y el mismo seguimiento de Cristo. La historia entera queda como separada en una forma sagrada y eterna, pues la Iglesia ya no tiene propiamente historia o, mejor, queda transformada en un concierto celeste. No cabe decir que Dionisio elimine el sentido de la historia. La verdad divina se inscribe como un evento en el centro del espacio y del tiempo. Y la unificación del mundo se realiza en la Resurrección, cuyo efecto se prolonga en los sacramentos. Las imágenes sagradas que habitan los sacramentos son el contenido de toda verdadera in-formación. Gracias a ellas alcanza el hombre material una forma según Dios.

La referencia a esta última etapa de la historia no es mera utopía, ya que, en si descripción, Balthasar, esboza cómo ésta se funda en un gozo que no es de este mundo. El acontecimiento comienza con la Encarnación que se anuncia como gran alegría y desemboca en la gran alegría y asombro de la resurrección y de la vuelta al Padre del Hijo de Dios. La dialéctica cristiana entre la cruz y el gozo remiten al misterio en el corazón mismo de Dios ${ }^{51}$.

La Iglesia, en cuanto cuerpo y esposa no es nunca el punto central de la forma sobre la que tienen que converger las miradas. Ella es luna, no sol. Reflejo, no la gloria misma. Lo que ella refleja en la noche es la luz de la esperanza para el mundo.

\section{Conclusión}

Narra Sören Kierkegaard la historia del mago Virgilio, quien se hizo cortar en pedazos y echar en una marmita para que lo cociesen durante ocho días y poder, mediante este procedimiento, rejuvenecer. De este modo, encargó a uno vigilar que nadie mirara la marmita, aunque el mismo vigilante no pudo rechazar la tentación: era demasiado pronto y, con un grito, Virgilio desapareció bajo la figura de un niño. También yo, sin duda, concluye Kierkegaard, he posado la mirada demasiado pronto en la

50. Cf. H.U. von Balthasar, Gloria, II. Estilos eclesiásticos, Madrid 1986, 143-205.

51. H.U. von Balthasar, Gloria, VII. Nuevo Testamento, Madrid 1989, 423-436.

Thémata. Revista de Filosofía №59 (2019) pp.: 13-34. 
marmita, en la marmita de la vida y del desarrollo de la historia y, por eso, no volveré jamás a ser un niño ${ }^{52}$.

Esta historia revela algo del proyecto de la razón omnímoda que pretende, bajo la forma de las matemáticas, el control de la realidad, a la que trata como un experimento. Controla todo, a condición de no mirar nada. Con la curiosidad del alquimista, el proyecto de la razón se desvanece sin haber podido cumplir su objetivo, al que había consagrado su esperanza. Los trozos del mago no pudieron ser reconstruidos, como la realidad diseccionada no puede ser reconducida a una unidad ideal y violenta que sofoca las diferencias. La unidad, propiedad trascendental del ser, quizá con arrugas en el rostro, ha sido sustituida por un juego de magia en el que el sujeto impone mediaciones categoriales e ideas que acaban sustituyendo a la realidad, o, de un modo más dramático, diseccionándola para no ser llevada más a la armonía antigua. Recuperar la belleza implica acoger el esplendor de una unidad que no ha sido impuesta desde fuera al ente en razón de ningún proyecto del sujeto, esto es, ganar para la metafísica un principio de realidad que se entrega como un don y que, con paciencia, el espíritu acoge y hace suya. De la belleza se ha escrito que es el trascendental capaz de reunir en sí todos los demás transcendentales, el esplendor de los transcendentales reunidos. Mientras que la unidad es la identidad del ser consigo mismo, lo verdadero es su identidad con el pensamiento, y el bien su identidad con la voluntad, lo bello es verdaderamente la identidad del ser con el espíritu, pues no es la unidad del ser con una función del espíritu, sino con todo el espíritu ${ }^{53}$. El carácter trascendental de la belleza añade así a los otros trascendentales una fuerza de totalidad de los que éstos no gozan por sí mismos: lo verdadero es el conocimiento del ser, el bien es su atracción, lo bello es su gozo. Bueno y verdadero, el ser es bello, es decir, el gozo y la felicidad del espíritu. De este modo, la belleza traba las potencias subjetivas del hombre, crea en él un eco del ente unido en sít ${ }^{4}$. La unidad de los trascendentales en tanto que unidad de la verdad y del bien, se da a sí misma una expresión particular esencial en la belleza, que debe tratarse como una propiedad transcendental del ser ${ }^{55}$.

La belleza permite que el hombre, de acuerdo con la imagen de Blaise Pascal, deje de mirar la caza de la liebre con mentalidad de carnicero y disfrute de aquella actividad que le otorga esparcimiento. Es decir, la belleza es capaz de rescatar de la crisis en las que, a juicio de Balthasar, las ciencias

52. S. Kierkegand, Aut-aut, I. Diapsalmata, Milano 1976.

53. A. MARC, Dialectique de l'affirmation. Essai de métaphysique réflexive, Paris 1952, 237.

54. P. Gilbert, Metafísica. La paciencia de ser, 383.

55. E. CoReth, Metaphysik: eine methodisch-systematische Grundlegung, Innsbruck 1964, $2^{a}$ ed., 396.

Thémata. Revista de Filosofía №59 (2019) pp.: 13-34. 
experimentales se adentraron cuando la perdieron de vista y la propia metafísica aceptó, cuando se sometió, vigía ella, al mandato del mago Virgilio, de controlar sin mirar, more geometrico. Frente a la facticidad (meras ciencias de hechos, rezaba Edmund Husserl, dan lugar a meros seres humanos de hechos), la belleza garantiza el estupor que da origen al pensamiento filosófico. El vigor de una mirada que, con libertad, pone sus ojos en la realidad y aborta un proyecto que, en el fondo, no era sino el de aquel emperador que se paseaba sin ropas mientras todos mentirosamente laudaban sus inexistentes vestidos. La belleza abre, en el contexto actual, a una mirada libre, que esboza una sonrisa y grita con inocencia: «jel emperador está desnudo!». 